\title{
A continuum of hate: delimiting the field of hate studies
}

\author{
Jennifer Schweppe ${ }^{1}$ (D) Barbara Perry ${ }^{2}$
}

Accepted: 5 July 2021 /Published online: 11 November 2021

(C) The Author(s) 2021

\begin{abstract}
A relatively nascent discipline, the field of hate studies has been explored and theorised from a multiplicity of disciplinary contexts. However, the field is ill-defined, and the relationship between hate crime and other related concepts unexplored. Here, we consider the range of phenomena which might fall within or without the field of hate studies, initiating a discussion of the boundaries of the field. We signal both the continuities and discontinuities among and between an array of strategies intended to sort and maintain hierarchical relationships, with the purpose of provoking scholars in the field of hate studies to reflect on its scope.
\end{abstract}

Keywords Hate crime $\cdot$ Hate studies $\cdot$ Microaggressions $\cdot$ Terrorism $\cdot$ Hate speech · Genocide $\cdot$ Extremism

\section{Introduction}

Hate studies, once considered a boutique or nascent field of study is now firmly embedded in scholarship, with academics across the globe seeking to understand, problematize, and combat hate. However, as a field which is necessarily and deliberately cross-disciplinary and international, scholars are still working to define and construct the field as a whole, as well as its relationship to other areas. As a discipline which had "hate crime" (broadly understood) as its core and original organising concept, we believe that it is time for scholars to move beyond thinking about 'hate

Jennifer Schweppe

Jennifer.Schweppe@ul.ie

Barbara Perry

Barbara.Perry@ontariotechu.ca

1 European Centre for the Study of Hate and School of Law, University of Limerick, Castletroy, V94 T9PX Limerick, Ireland

2 Faculty of Social Science and Humanities, Ontario Tech University, 2000 Simcoe St., North Oshawa, Ontario L1H 7C1, Canada 
crime' and seek to explore other manifestations of hate. Thus, this article seeks to consider the field of hate studies in an expansive manner, creating what might be considered the start of a taxonomy for the field.

Thus, our contribution here is an attempt to parse out the kinship lines between hate crime and an array of what we argue are closely related concepts. We seek to understand, explore and tentatively (re)define the boundaries of hate crime for the discipline that has come to be known as 'hate studies' from our two disciplinary perspectives, sociology and law. It will also suggest a delimiting of the term hate crime, in an attempt to distinguish the concepts and constructions of other forms of targeted hostility. The intent is to draw attention to the dynamic relationships among and between the continua of hate and other strategies of difference-making: microaggressions, hate speech, hate crime, terrorism, and genocide. Indeed, the expression of hatred can be understood within and across the continuum of hatred, from a 'throwaway comment' as a microaggression, to the inclusion of 'direct and public incitement to commit genocide' as requiring punishment by States Parties under Article 3 the Convention on the Prevention and Punishment of the Crime of Genocide from 1948 (see also, the International Convention on the Elimination of Racial Discrimination; the International Covenant on Civil and Political Rights). In recent years, extremism has been the subject of scholarly attention by hate scholars, and we will explore this problematic and challenging concept of extremism, and contextualise it within the context of hate studies.

We take a range of cognate concepts - microaggressions, hate speech, terrorism, genocide, and extremism - and document similarities and differences between these and hate crime. By articulating the relationships and inter-relationships of concepts, we can start to draw out the field of hate studies. We argue that, while on the surface, genocide and terrorism, for instance, would seem to be of an order of intensity to warrant significant distancing from something as 'common' as hate crime, this is our goal precisely, that is, to explore whether such distancing is warranted, or whether these experiences and understandings deserve and demand further attention from the academy of scholars. Brudholm (2016) asks whether linking hate crimes with human rights violations, for example 'support(s) the combatting of daily occurrences of biasmotivated violence in everyday contexts.' We would argue that it does, in that these parallel constructs at once point to the barbarism (genocide) and the banality (microaggressions) of hate. Awareness of the ways in which unchecked targeted violence can escalate to genocide is a stark reminder of the long-term implications of hate. Yet at the other end of the spectrum, recognizing the interplay of microaggressions with hate crime highlights the fact that, for many communities, bias-motivated harassment and violence are daily threats, if not realities.

A Canadian example highlights the potential conceptual and practical relationships among a number of different notions. On January 29, 2017 a lone gunmen entered the Islamic Centre of Quebec in a suburb of Quebec City, Quebec, intent on killing Muslims. He opened fire with his long gun, murdering six Muslim men and injuring 19 others while they prayed in the Centre (Perreaux \& Freeze, 2017). The shooter was described by his friends as a moderate conservative who, over the past year, had become an apparent xenophobe and racist, one who overtly supported Donald Trump and far-right French politician Marine Le Pen (Dougherty, 2017). How do we best characterize this violence? Legally, it is likely a hate crime or an act of terrorism. Can 
we also - or alternatively - characterise it as extremist violence? It is the overlaps between these concepts and legal constructions which inform our analysis.

Our hope here is to make a contribution to the field of hate studies by considering a range of concepts which ought to catch our attention and which deserve our scrutiny in the field of hate studies, using hate crime as a pivot or lens through which to understand and explore related phenomena. We use this as the focal comparator as it is construct that has come to dominate conversations about hate. We want to initiate a discussion of the boundaries of our field, signalling both the continuities and discontinuities among and between an array of concepts. We begin first by exploring the history and development of the field of hate studies, and then move on to elaborate on "hate crime" as it has been understood by the field, articulating its core organising concepts. Drawing on these concepts, we then go on to discuss the other manifestations of hatred we believe relevant to the field. This is clearly not intended to be an exhaustive account, but rather a first step in critically reflecting on some of the phenomena that might be seen to be closely aligned with the field of hate studies. For this initial treatment, we explore microaggressions; hate speech; terrorism; and genocide. We end by a consideration of a particularly challenging and slippery concept - extremism.

This discussion, whilst timely, is not exhaustive. We do not consider workplace or educational discrimination. Equally, we have not touched upon sexual violence or rape, for example, the latter often being considered the 'paradigmatic' hate crime (Hodge, 2011; McPhail, 2002; Walters \& Tumath, 2014; Campo Engelstein, 2016). Nor have we considered the links between the violence of hate and human rights violations (Brudholm, 2016; Perry \& Olsson, 2009). Rather, we seek to describe and understand the continuum of hate from the micro to the macro, and ultimately seek to begin a discussion about the parameters and boundaries of a maturing field of study.

\section{Understanding hate and defining hate crime}

However, where a community of scholars seeks to explore and understand a phenomenon, we should, at the very least, clearly state the boundaries of how we understand the phenomenon or process under investigation. We should begin by articulating what we understand to be "hate" - the term at the heart of our field of studies. As Neil Chakraborti and Jon Garland (2015) insist,

. . . 'hate' is a slippery, emotive and conceptually ambiguous label. Hate can mean different things to different people, and that has important implications for the way in which we conceive of the offences that fall under its umbrella framework (Chakraborti \& Garland, 2015, 2).

Similarly, Nathan Hall (Hall, 2005, 233) suggests the breadth of possible interpretations of "hate": 
... this simple four-letter word, 'hate', in fact masks a multitude of complexities .

.. because of this, 'hate' in its contemporary meaning actually refers to variety of

human emotions that are often far removed from real hatred.

Yet hate as we understand it in the context of the sorts of phenomena we are exploring here is not simply or always an emotion; rather, for us, it also rigidly structured patterns of oppression - it is about race and racism; sex and sexism and heterosexism, for example. This perspective on hate (and ultimately, hate crime) crime removes it from the realm of "cultures of violence," placing it instead in the realm of the psychology of violence (Ray \& Smith, 2001; Goldberg, 1995). In this respect, biases are socially reinforced and not simply personal; their acts are not uncommon and often are considered rational in their social context (Wang, 1999, 818).

In this context, hate is at once part of and symptomatic of larger patterns of intergroup conflict, and especially of subordination. It is embedded in the structural and cultural context within which groups interact (Young, 1990; Bowling, 1998). It is a social practice nested within the context of the "birdcage" of oppression (Frye, 2007, 148) which systematically restricts the capacities and autonomy of its victims. It "is not - or more exactly is not simply or only-about hate. .. [it involves] normal inductive reasoning and not necessarily the prejudice of affective - hateful - animosity" (Goldberg, 1995, 269-270). In other words, hate crime, for instance, is not simply grounded in a mental state; nor is it the outcome of extreme hostility or pathology. Rather, it is more often foreseeable, and rational, at least from within the worldview of the perpetrator. Anti-LGBT violence that is conditioned by a particular reading of scripture is not irrational; it is not necessarily even grounded in animosity or some other negative affect. Violence emerging in these contexts, then, is not "about" an emotive state, but is "about" the assertion of one's own identity and belongingness over and above others - in short, about power. It reflects much more than the perpetrator's state of mind. In fact, it reflects the taken for granted, popular notions of identity and hierarchy.

There is, then, nothing irrational or pathological about engaging in racist violence, for example, in a decidedly racist culture. It is, rather, wholly rational given the array of institutionalized practices and discourses that lend permission to minimize or victimize the Others in our midst. Hate crime, then, is nested in a web of everyday practices that are used to marginalize and disempower targeted communities. It resonates with a network of norms, assumptions, behaviors, and policies that are structurally connected in such a way as to reproduce the identity-based hierarchies that characterize so many Western cultures. In this respect then, hate crime is as normal and as usual as alternative mechanisms of oppression, such as cultural stereotyping or employment discrimination.

Despite its relative maturity, key concepts and terms remain contested in the field of hate studies more broadly, both within and across disciplines, and within and across jurisdictions. Thus, coming to this paper as we do from two disciplines - law and criminology - we are very much aware of the tension between legal and conceptual analyses of the ties that bind hate crime and the other constructs we explore here. It is commonly accepted amongst scholars in the field of hate studies that a global definition of hate crime is not available - nor, as Perry would argue, is it perhaps possible given 
the historical and cultural context of hate crime (Perry, 2001). ${ }^{1}$ Brudholm observes that consensus on the definition of a hate crime is both improbable and 'to some degree undesirable' (Brudholm, 2016, 31-46). Various efforts have been made to describe the phenomenon of hate crime, as well as to legally define a hate crime. In one sense, it is perhaps unwise to have a definition of hate crime which is acceptable to all: historical, legal, cultural, and geographic influences will all influence local or regional definitions of hate crime. Iganski suggests that, rather than

referring to this or that type of crime it is perhaps more pertinent to think of 'hate crime' as a policy domain, an arena in which elements of the political system and criminal justice process have converged and focused on the substantive issue of offences and incidents where some bigotry against the victim plays a part... (Iganski, 2008, 5)

While violence against racial, ethnic and religious minorities, against members of the LGBT community, and against disabled people have been historical constants, most scholars trace the origins of the concept now known as hate crime to the 1980s, and specifically to American legislative reforms in that period. An early form of hate crime was first recognised in the the Civil Rights Act 1968, and ten years later, the State of California introduced its legislation. The real "flurry" began, however, with the signing of the Hate Crime Statistics Act of 1990. By the end of the 1990s, virtually all US states had hate crime legislation. Most other western nations seem to have followed suit, introducing their own variants during the late 1980s and throughout the 1990s. Interestingly, while US law often explicitly used the umbrella term "hate crime" in the text of the legislative provision, legislation in England and Wales uses the term 'hostility', as does New Zealand. The Canadian legislation uses the terms 'bias, prejudice, or hate', and Scotland uses the phrase 'malice and ill-will'.

Obviously, the violence of which we speak did not suddenly emerge in the 1980s, but the formal recognition of the violence as a coherent class was, in many respects, a natural outgrowth of mid-century activism on the part of long oppressed groups. It was a not altogether surprising coalition of related anti-violence projects the 1970s and 1980 s that forced the issue among legislatures across the US in particular. Valerie Jenness $(2002,20-21)$ summarizes the overlapping agendas of those involved:

“... the civil rights movement politicized violence against racial minorities, such as police brutality against Blacks; the women's movement politicized violence against women, including rape and domestic violence; the gay and lesbian movement politicized violence against homosexuals, especially 'gay bashing'; and the disabilities rights movement politicized violence against persons with disabilities, such as the so-called "mercy killings' of those deemed unfit to live meaningful lives.

\footnotetext{
${ }^{1}$ See also, Boeckmann and Turpin-Petrosino(2002, 208), where they note, 'cultural differences, social norms and political interests play a large role in defining crime in general and hate crime in particular.'
} 
Oddly, academics did not seem to keep pace with either legislators or activists. We were much slower to recognize this emerging construct. Michael Shively $(2005,4)$, in a National Institute of Justice Report writes that "While there is a long history of research on crimes motivated by bias and bigotry. .. the term "hate crime" did not appear with any substantial frequency in the social research literature until relatively recently. Studies in which hate crime is so named and defined (in ways consistent with contemporary hate crime statutes) have grown from the occasional study in the 1980s. .. to a steady flow over the past ten years." Certainly, there were no major works with "hate crime" in the title prior to the mid-1980s. In fact, few references of any kind are to be found in the scholarly literature, until 1989 and 1990, which seemed to be watershed dates, perhaps in line with debates in the US House around the 1990 Bill. The field really took off in the opening years of the 1990s, with the publication of such works as Kelly's (1993), Herek and Berrill's (1992), and Levin and McDevitt's (1993).

Attempts have also been made to legally define (as opposed to criminologically understand) hate crime (see, Walters, 2014; Schweppe, 2021). In doing so it is important to observe that legislatures generally distinguish between criminal expressions of bigotry (hate speech) and the commission of criminal offences with a bias element (hate crime). Hate speech offences - or more particularly, incitement to hatred offences - are generally considered separate to and apart from hate crime laws. Even so, there is no universally accepted definition of hate crime, and for this reason, Schweppe, Haynes and Walters argue that, from a policymaking perspective, and especially at an EU level, there should be coherency in the conceptualisation of a hate crime:

As we have seen, there is no common definition of hate crime across Europe, either formal or informal. Across Member States ... a range of interpretations of the concept of hate crime are in evidence. At this conceptual level, we see key differences in the way that hate crime is understood, which speak, we assert, fundamentally to the different ways in which hate and hostility have manifested historically across the Member States. (Schweppe et al., 2018, 137).

In his excellent articulation of how hate can be conceptualised globally, Brudholm observes that there are four 'constitutive features' of hate crimes globally (Brudholm, 2016):

1. If there is no crime, there can be no hate crime;

2. There is general agreement that the proof of the hate crime lies in the answer to the question why the crime was committed;

3. Implied in the definition is a requisite relation between the hate and the crime;

4. There is also implied a specification of a list of protected characteristics: the hate must be directed towards categories of group identity.

The Organisation for Security and Co-operation in Europe's Office for Democratic Institutions and Human Rights proposes a generalised definition applicable across boundaries. Hate crimes, it suggests, are 'criminal acts committed with a bias motive' (OSCE, 2009, 16). Thus, a hate crime is not a specific offence, but rather a 'type of crime', 
and can be committed in a country, the OSCE/ODIHR argue, 'where there is no specific criminal sanction on account of bias or prejudice' (OSCE, 2009, 26). This is important: hate crime statutes do not typically introduce new forms of offences, but rather attach a bias element on to existing offences. Useful as a starting point, the OSCE/ODIHR definition lacks what we regard as the crucial ingredient to a hate crime: that the bias is directed towards targeted minoritised community. Gerstenfeld's definition resolves this: 'a criminal act that is motivated, at least in part, by the group affiliation of the victim' (Gerstenfeld, 2013, 9). The term motivation, of course, has particular resonance in a legal context, and at least in England and Wales there is no requirement to evidence a hatemotivation: demonstration of hatred is sufficient to move a crime across the threshold to become a hate crime; Lawrence's 'discriminatory selection' model requires that the perpetrator selected his or her victim because of their identity characteristic - no 'motivation' is required in this context. Gerstenfeld's definition also lacks a requirement for that motivation to be based on hate, prejudice bias or hostility (see also, Brudholm, 2020). Thus, the field remains, if not divided, then perhaps confused as to what a 'hate crime' is. For the purposes of this article, we adapt the ODIHR definition as a useful starting point: a hate crime is, first and foremost a crime - that is, an offence which is known to the criminal law which is committed with a 'hate' element (eg motivated by hostility). By definition, then if it is not possible to disaggregate the hate element from the crime, we argue here that the offence does not constitute a hate crime. Incitement to hatred offences, then, do not constitute hate crimes.

Moving away from narrow and pragmatic legal definitions to more inclusive and theoretically driven criminological ones, Perry observes that hate crime is like no other crime, as its dynamics both 'constitute and are constitutive of actors beyond the immediate victim and offenders'. Hate crime, according to Perry:

... involves acts of violence and intimidation, usually directed toward already stigmatised and marginalised groups. As such, it is a mechanism of power and oppression, intended to reaffirm the precarious hierarchies that characterise a given social order. It attempts to re-create simultaneously the threatened (real or imagined) hegemony of the perpetrator's group and the 'appropriate' subordinate identity of the victim's group (Perry, 2001, 10).

Chakraborti and Garland (2015) propose what they refer to as a simpler 'and in some ways broader' definition in their research, that is by defining hate crimes as "acts of violence, hostility and intimidation directed towards people because of their identity or perceived 'difference'." This definition is useful as it includes hate incidents as well as hate crime, which have, as Garland and Funnell argue, 'just as significant an impact on the victim, their family and wider communities' and is one step removed from the 'complex, ethereal' academic definitions set out above (2016, 15-27).

\section{Measuring hate crime}

Given the challenges of defining hate crime, it is perhaps not surprising that measuring hate crime also presents difficulties. This problem is, of course, exacerbated in the 
countries like the US, and in EU context where member states have diverse pieces of legislation, covering a wide array of different offences, protected categories, and/or sentencing responses. Reports from OSCE, and from the EUMC, for example, consistently bemoan the lack of standardization across EU states. In fact, some states have no specific provisions on hate crime (e.g., Ireland). A 2009 OSCE report on hate crime laws includes an overview of the different protected categories among member states, including the most commonly protected classes (e.g., race); frequently protected classes (e.g., gender); rarely protected classes (e.g., political affiliation). Similarly, states vary on the nature of the legislation, ranging from genocide to sentencing enhancement, to hate speech provisions.

These discrepancies have obvious implications for the abilities of law enforcement agencies to collect and record what is deemed relevant data. Add to this the disparities in police training in the identification of hate crime, and the frequent resistance to recognize the phenomenon, and you have a recipe for imprecision. Because the hate crime data are collected in the same way as the other official police data, they are fraught with the same deficiencies. Bell identifies an array of structural limitations on police recording of hate crime. Different levels of organizational procedure exist around hate crimes. In order to be reported, hate crimes must be recognized, counted, and eventually reported. There are vast differences between police departments whether, the degree to which, and in what way officers are trained. Consequently, in the US, for example, it appears that very few departments are effective in identifying or investigating hate motivated crime. On the contrary, very few acknowledge hate crime when it occurs. For instance, in 2019, only $14 \%$ of the agencies reported any hate crime; most departments in the Deep South reported fewer than 5 incidents for the year, which many would find incredible.

In addition to the limitations imposed by law enforcement agencies are those presented by trends in public under-reporting. In fact, some argue that hate crimes are even more dramatically under-reported than other UCR offences. Gay victims, for example, may fear that the admission of their victimization is concomitantly an admission of their sexual orientation. Reporting an anti-gay crime to the police is tantamount to "outing" themselves an event for which they may not be prepared. Moreover, victims may well fear secondary victimization at the hands of law enforcement officials. At the very least, they may perceive that police will not take their victimization seriously.

\section{Impacts of hate crime}

While the concept of hate crime has not been narrowly defined, and measurement challenges persist, what we do know is that when an individual is the subject of targeted violence, the impacts can be considerable. It is accepted internationally that hate crime is likely to have a more significant impact on its victims than non-hate motivated offences (Iganski, 2008; Paterson et al., 2019; Walters, 2020). Direct impacts can range from physical injury to emotional and psychological harm. We now know that there is a qualitative difference to the impact of hate crime as compared to non-hate motivated incidents. For instance, data from the Crime Survey for England and Wales showed that victims of hate crime were more likely than victims of crime overall to say they were emotionally affected by the incident ( $92 \%$ and $81 \%$ respectively) (Corcoran et al., 2015, 22), while $36 \%$ of hate crime victims stated they were 'very much' affected 
compared with just $13 \%$ for non-hate crime victims. The data also showed that twice as many hate crime victims suffer a loss of confidence or feelings of vulnerability after the incident compared with victims of non-hate crime (39\% vs. $17 \%)$. Hate crime victims were also more than 'twice as likely to experience fear, difficultly sleeping, anxiety or panic attacks or depression compared with victims of overall CSEW crime' (Corcoran et al., 2015, 22; see also Herek et al., 2002).

Perry (2001)observes that the impacts of hate crime go far beyond the physical or financial or indeed personal: hate crime, she says, 'reaches into the community to create fear, hostility, and suspicion.' Thus, hate crime not only impacts its direct victims: the targeting of victims on the basis of their membership of a particular community 'communicates to all members of that group that they are equally at risk and do not belong' (Haynes \& Schweppe, 2017, 130). Paterson et al. conducted a study involving over 3000 LGBT and Muslim people which found that knowing other people who have been the victim of hate crime increases the perception of threat in those indirect victims. This in turn is linked to heightened feelings of vulnerability, anxiety and anger (Paterson et al., 2018a, b). These heightened emotions are evidence of the terrorising effects of hate crime, on the broader community of which the victim is part: what the European Union Agency for Fundamental Rights (FRA) refers to as the 'resonating nature of hate crime' $(2012,18)$, or what Perry and Alvi have referred to as the 'in terrorem' effect of hate crime (Perry \& Alvi, 2012). Hate crime, then, can be perceived as 'symbolic crimes' that communicate Otherness and operate as an exclusionary practice (Perry, 2003). They have the effect of regulating marginalised social groups. Indeed, the targeted community must be counted as secondary victims of the offender (Chakraborti \& Garland, 2015; Hall, 2005; McDevitt et al., 2001).

Another related area that has received scant attention has been the impact of hate crime on perceptions of national ideals. Hate crime throws into question not only the victim's and the community's identity, but also national commitments to tolerance and inclusion. Speaking specifically of Native Americans over fifty years ago, legal scholar Felix Cohen noted that mistreatment - legal or extralegal - of minorities "reflects the rise and fall of our democratic faith." In other words, it is possible that the persistence of hate crime is a challenge to democratic ideals. It reveals the fissures that characterize its host societies, laying bare the bigotry that is endemic within each. As such, it may very well be the case that bias motivated violence is not just a precursor to greater intergroup tension, but is an indicator of underlying social and cultural tensions. In this interpretation, hate crime is but one indicator that enshrined ideals of freedom and equality are illusory.

The widely proclaimed ethos of inclusion and belonging is not necessarily the daily reality for vulnerable communities who both experience and fear violence motivated by ideals in direct contrast to those embedded in the national mantra. The messages of inclusion, participation, and engagement are matched by their mirror images in the acts of violence inspired by racism, heterosexism and other related "isms." Writing of the Australian paradox, Chris Cunneen $(1997,138)$ highlights the irony wherein "a liberal democracy, with its commitment to anti-discrimination, simultaneously functions within an institutional framework which can be described as having pervasive racism." The cultural, social and political mood in western nations like Canada and Australia uneasily supports both a disabling and enabling environment for hate.

Hate crime challenges the sense of belonging that would seem to be so crucial to inclusive societies. Hate crime can be a key point of contact in the negotiation of place 
and belonging. Indeed, Perry (2001) has long argued that hate crime is a crucial mechanism for the dance of power; it is an unequal exchange, whereby the intent is to dominate and exclude, rather than to build positive connections. Indeed, hate crime is explicitly meant to transmit a key message that victims are not worthy of belonging:

A sense of belonging is crucial to social inclusion. Yet people of colour, members of religious minority groups, and members of the LGBT communities, for example, are frequently reminded by harassment and violence that they do not warrant the same recognition as their straight, white, Christian counterparts. The sense of alienation emanating from this exclusion can be debilitating to the extent that it has the potential to promote withdrawal from engagement with the broader society, in that "persons who do not feel valued in society cannot contribute or participate to their full potential" (OHRC, 2003, 34).

Interestingly, there is yet another potential individual and community response to targeted violence, and that is mobilization whereby hate crime acts as a catalyst to positive change. That is, patterns of persistent violence, or highly publicized cases - like the 1998 Matthew Shepard or James Byrd cases - often have the unintended effect of mobilizing victim communities and their allies. Indeed, across multiple studies that Perry has conducted, for example, the targets of hate violence can and do develop constructive alternatives to the prejudice and violence that confronts them. One First Nations male indicated that hate can be unlearned. "I think it is learned. It is learned partly in our educational system, it is learned in the home and is learned through the media culture. I would suggest that the only good news is that hate can be unlearned."

Whether individually or collectively, there is value in challenging hate crime and the biases that inform it. There were participants who were relatively optimistic about the potential for change, and who suggested progressive strategies for harnessing the energy of vibrant communities to counteract both the potential for and the impact of hate crime. For example, "This story makes me want to help educate people so that future generations will be more accepting and less afraid. Education is the key to eliminating irrational fears" (Jewish male). The anger, frustration and anxiety evoked by such violence can motivate individuals and communities to action.

\section{Toward a taxonomy of hate?}

What, then, can we say about hate crime that will allow us to consider its place within a broader taxomony of hate studies? First, and perhaps most critically, hate crime - however understood - is identity-based. It is directed against an individual because of their personal characteristics (or presumed personal characteristics, or their association with an individual with those characteristics). Thus, the victim is in one sense targeted because of that characteristic - but in another sense, they are chosen not because of who they are, but of what they represent. Such crimes are committed as a means to control the victim, and to assert power and dominance over them, in short, to reinforce their presumed marginality. Through being victimised in this way, the victim is marked as Other, and is told that they do not belong. In so doing, as noted above, they inflict an array of physical and emotional harms. Beyond that, however, indirect victims also feel the impacts in parallel ways. Finally, in most western nations, there is a statutory recognition of this form of targeted violence, although it goes by many names. 
We can summarise some of the key factors we consider relevant in tabular form:

\begin{tabular}{|c|c|c|c|c|c|}
\hline & $\begin{array}{l}\text { Identity- } \\
\text { based }\end{array}$ & $\begin{array}{l}\text { Reinforcing of victims' } \\
\text { marginality }\end{array}$ & $\begin{array}{l}\text { Harmful to the direct } \\
\text { victim }\end{array}$ & $\begin{array}{l}\text { Collective } \\
\text { victims }\end{array}$ & $\begin{array}{l}\text { Legal } \\
\text { definition }\end{array}$ \\
\hline Hate crime & $\mathrm{x}$ & $\mathrm{x}$ & $\mathrm{x}$ & $\mathrm{x}$ & $\mathrm{x}$ \\
\hline Microaggression & $\mathrm{x}$ & $\mathrm{x}$ & $\mathrm{x}$ & $\mathrm{x}$ & \\
\hline Hate speech & $\mathrm{x}$ & $\mathrm{x}$ & $\mathrm{x}$ & $\mathrm{x}$ & $\mathrm{x}$ \\
\hline Terrorism & $\mathrm{x}$ & $\mathrm{x}$ & $\mathrm{x}$ & $\mathrm{x}$ & $\mathrm{x}$ \\
\hline Genocide & $\mathrm{x}$ & $\mathrm{x}$ & $\mathrm{x}$ & $\mathrm{x}$ & $\mathrm{x}$ \\
\hline Extremism & $?$ & $?$ & $\mathrm{x}$ & $?$ & \\
\hline
\end{tabular}

Our aim here is to determine whether and to what extent potentially similar phenomena share a lineage with hate crimes, and therefore constitute apt candidates for inclusion in the broader field of hate studies. Are they shaped by similar intentions, and do they have similar effects? Who are the targets, and what is the breadth of their impacts. We move, now, to consider other related concepts, and their relationship to hate crime, in an effort to broaden and delineate the field of hate studies. The list of concepts is clearly not intended to be exhaustive, but to suggest the range and breadth of inclusive categories of conduct, and to inspire further consideration of areas of inquiry not explored here.

\section{Microaggressions as hate incidents}

According to Nadal (2008), microaggressions can be understood as 'commonplace verbal, behavioural or environmental indignities, whether unintentional or intentional that communicate hostile, derogatory or negative slights and insults toward members of oppressed groups' (Nadal, 2008, 23). They are the everyday affronts experienced by people from minoritised groups, running the gamut from shunning individuals, to telling offensive jokes, to identitybased insults and harassment (Sue et al., 2008; Constantine, 2007). More specifically, Sue etal. (2008) identify three classes of microaggressions: microassaults, microinsults, and microinvalidations. The term microassaults refers to intentionally pejorative and/or discriminatory language and behaviour. Microinsults, in contrast, are likely to be unintentional, but nonetheless offensive and insensitive. Finally, microinvalidations trivialize or call into question the lived experiences of minoritised groups. From a legal perspective, the context in which these microaggressions occur can be relevant: they can, on occasion, amount to criminal offences (for example, in the context of public order offences); where they do not amount to harm for the purposes of the criminal law, if they occur in the context of the workplace, or in the context of the provision of goods and services, for example, an action could be taken under equality legislation.

Cumulatively, these incidents can have severe deleterious effects on targeted communities. For individuals and communities who are the targets or even bystanders to such incidents - in classrooms, workplaces, peer groups - they are constant reminders that they are not valued, and that the harms they feel are not important. Indeed, there is ample evidence to suggest that non-criminal expressions of hostility are commonplace. Most 
research with targeted communities uncovers both non-criminal and criminal expressions of hate and hostility. In a 2017 report on transphobic crime in Ireland, for example, respondents reported experiencing a range of microaggressions including 'the use of transphobic and/or incorrectly gendered terminology', 'endorsement of gender normative and binary culture or behaviors', and disrespect (Haynes \& Schweppe, 2017). Of the 79 reports logged for the years 2014-2016, 32 identify acts of discrimination, microaggression, and/or harmful communications occurring in the Republic of Ireland. Across the three years a total of 34 such non-crime hostile actions were identified for that jurisdiction (Haynes \& Schweppe, 2017). While not criminal manifestations of transphobia, nor ones which would come under the protection of equality legislation, their emotional and psychological impact makes them part of a continuum of hostility, which includes discrimination and hate crime. They both reflect and contribute to a culture within which some people may feel emboldened to make manifest their prejudices against the trans community.

While non-criminal occurrences may not typically be of interest in a criminal justice context, Perry observes that non-crime hate incidents have a very negative impact on both victims and society, with victims relating that ' $\ldots$ by their very frequency and ubiquity, some of the most minor types of victimisation - name calling, verbal harassment, and so on - had the most damaging effects' (Perry, 2009, 402). This is recognised by ACPO, which states that non-crime ' $[\mathrm{h}]$ ate Incidents can feel like crimes' and need official recognition if they are to be challenged (Association of Chiefs of Police (ACPO), 2018, 60). Recognising everyday acts of hostility is vitally important, speaking as they do to the existence of a continuum of criminalised and noncriminalised hate incidents, both of which contribute to the exclusion of marginalised communities. Perry and Dyck (2014)observe that when people use transphobic language against trans people, for example, the victim is left wondering whether perpetrators will cross the line into violent acts: 'a very fine line indeed' (Nadal et al., 2011, 234-259). Further, given the relationship between the commission of hate incidents and hate crimes, ACPO observes, hate incidents should be recorded, not only to acknowledge their impact, but also to prevent an escalation of hate incidents into hate crimes.

This is very much in line with what we know generally about the nature and distribution of hate. It does tend to be largely restricted to incidents at the lower end of the spectrum, what are more properly referred to as bias incidents, rather than bias crimes. But, as suggested above, that does not make them any less significant. We have learned from the literature on violence against women, for example, that the daily onslaught of verbal abuse has far-ranging consequences for the victim. The same can be said of racial harassment, to the extent that it is also an almost daily occurrence in many communities. One participant in Perry's (2009, 401-402) study of Native American victimization, for example, stated the impact very simply: "A lot of it is petty stuff. But it's the petty stuff that gets to you after a while, because it's all the time." The regular barrage of otherwise mundane and seemingly trivial forms of harassment microaggressions - ultimately disempowers victims of targeted violence. These incessant and pervasive microaggressions - along with more serious forms of victimization wear down their victims, as intended. It is the collective impact of multiple incidents that renders these manifestations of hate so debilitating.

As ACPO's position suggests, just as significant as their legal affinity to hate crime, is the fact that microaggressions may well be precursors or even accompaniments to bias motivated crimes. They, too, are expressions of the taken-for-granted superiority of 
the perpetrator's group, and thus have the capacity to escalate to hate crimes if left unchecked. This is perhaps most readily apparent in schools, where youths' microaggressions are often euphemized as 'teasing' and allowed to continue without intervention. Emboldened by what might be seen as tacit approval, the perpetrators often ratchet up their attacks into increasingly physical forms of aggression (Wessler, 2000; Hall, 2009; OSCE/ODIHR, 2009). In the absence of any form of intervention, intensification of the assaultive language and actions is a possibility (Wieland, 2007).

Microaggressions are often understood in a criminal justice context by law enforcement services as hate 'incidents.' A hate incident is a non-criminal occurrence with a hate element attached to it. Often used for reporting and recording purposes on the part of police services, the definition of a hate incident is often broader and more and subjective than that of a hate crime, incorporating microaggressions. In England and Wales and Northern Ireland, definitions of hate incidents are informed by the definitions of racist offences emanating from the Macpherson report on the murder of Stephen Lawrence (Macpherson, 1999).

While the relationships and interrelationships between hate incidents and hate crimes from a policing perspective are clear (what is does not reach the threshold of a crime is almost by definition a hate incident), the relevance of 'microaggressions' or 'microinsults' to the field from a broader perspective are, at least currently, perhaps more contested. While scholars are comfortable articulating microaggressions from a criminological perspective, the field has yet to explore relationships between hate incidents and discrimination as defined in equality legislation. Indeed, there are few if any scholars who bridge the gap between the legal domains of hate crime and equality law, articulating and describing the links and relationships between the two. From a legal perspective, this is perhaps understandable: legal scholars, for example, typically work in the public domain of criminal law or the private domain of employment or contract law. From this perspective, it is perhaps time for the field to broaden in this regard - when we consider hate studies, we must remember that hate and its associates take many forms beyond those acts which are considered within the range of the criminal justice process.

\section{Hate speech}

Put simply, hate speech is the verbal or written manifestation of hatred, prejudice, or hostility. We see clear interrelationships between the conceptualisation and performance of hate speech and our other manifestations of hate. As Waldron notes, the term hate speech can cover:

... things as diverse as Islamophobic blogs, cross-burnings, racial epithets, bestial depictions of members of racial minorities, genocidal radio broadcasts in Rwanda in 1994, and swastika-blazoned Nazis marching in Skokie, Illinois, with placards saying 'Hitler should have finished the job' $(2012,34)$. 
There are clear links between hate speech and hate crime, especially in temporal terms. The examples noted by Waldron point to this. Verbal vilification of targeted communities often precedes the violence that might then befall them. In recent memory, this has most clearly been the case in Rwanda, where state and media rhetoric set the stage for wholesale slaughter of entire Tutsi communities. In addition to vilifying Tutsis, politicians and media pundits alike explicitly called for the extermination of that group. What began as isolated attacks on individuals and small communities soon intensified to the level of mass executions (Yanagizawa-Drott, 2014; Kellow \& Steeves, 1998).

Moreover, 'speech' - that is, spoken language, written words, gestures and symbols - is also often key to distinguishing between a hate crime for the purposes of the criminal law (at least in practice) and an ordinary crime: the hate element to a crime is most often evidenced through the presence of what we might call hate speech in the commission of the criminal act. Indeed, most 'check-lists' of hate crime indicators include some reference to the use of slurs, racial or other epithets, or the display of offensive symbols (e.g., a swastika). That is, hate speech may immediately give rise to violence, or be invoked in the context of committing a bias motivated assault.

It is also important to note the parallels between hate speech and hate crime in terms of harm. Hate speech as a microaggression might be considered to be at the lower end of the spectrum in terms of severity and intensity. However, the frequency and ubiquity of offensive language, of racial insults, of homophobic slurs means that their impacts are often felt in very dramatic ways. Because of their 'everyday' nature, hateful utterances and symbols can have deep and lasting effects on communities (Waldron, 2012). Moreover, the effects are not limited to individual targets. Oftentimes, these speech acts are broadly directed at a group rather than an individual, where pamphlets denying the holocaust are printed and distributed, or a transphobic rant is posted online. There, the message is diffused across the community. This is very much in line with the collective harm associated with hate crime (Paterson et al., 2018a, b; Perry \& Alvi, 2012). In a related vein, Goodall (2010) comments on another dimension of the 'audience' for hate speech. She observes that one of the key differences between hate speech offences and hate crimes is what she refers to as the audience of the crime which 'does not necessarily include the victim, but is rather a separate audience who can be stirred up', and it is this distinction, and the extent to which hate speech can and should be criminalised, which is perhaps one of the more contentious issues in the field of hate studies.

From a legal perspective, hate speech and hate crime are two completely separate concepts and are constructed differently. Also, crucially, not all hate speech is criminalhate speech. Typically, legislation will criminalise 'incitement to hatred' or 'stirring up hatred', and such offences have a much longer statutory pedigree than hate crime, dating back to reconstruction-era civil rights statutes and early twentieth-century state statutes aimed at the activities of white supremacist organizations (Phillips \& Grattet 2000, 572). Similarly, the British Race Relations Act 1966 criminalised incitement to racial hatred, as did the Irish Prohibition of Incitement to Hatred Act 1989. That said, from a legal perspective, the criminalisation of hate speech is not unproblematic, often seen as being in direct conflict with rights to freedom of expression (see, for example (Kiska, 2012).

Pejchal and Brayson note that attempts to limit free speech are sometimes seen as an 'attack on the foundations of Western society, where freedom of expression has been 
considered a developmental cornerstone' (2016, 247). This argument was successful in the US Supreme Court case ofRAV v City of St Paul, Minnesota, where the applicant was charged with burning a cross on the lawn of a black family under the city's BiasMotivated Crime Ordinance, which prohibited the display of a symbol (including a Nazi swastika symbol or burning cross) that the offender knew or had reason to know 'arouses anger, alarm, or resentment in others on the basis of race, color, creed, religion or gender' $(1992,380)$. This ordinance was deemed unconstitutional by the US Supreme Court on the basis that it proscribed words directed against particular victim groups in violation of the free speech provisions of the First Amendment. When we compare the case law of the United States with that of other western democracies, however, we see that in some jurisdictions that legal system recognises the harms of hate speech as outweighing the right to unlimited freedom of speech. Through the operation of both Article 10 (which sets out both the protection for and limitations on the freedom of expression) and Article 17 of the of the European Convention on Human Rights and Fundamental Freedoms (which was stated in Glimmerveen and Hagenbeek $v$ The Netherlands (n.d.) as having a general purpose of preventing 'totalitarian groups from exploiting in their own interests the principles enunciated by the Convention') the European Court of Human Rights has upheld laws which criminalise hate speech (Norwood v United Kingdom (n.d.). Further, hatecrimelegislation has been upheld when its compliance with the freedom of expression was considered (see, eg Wisconsin v Mitchell, 1993).

The relationship between microaggressions, hate crime, and hate speech is often considered close, and the three are regularly conflated and confused. This is unsurprising - a victim will rarely know where the boundaries between a racially aggravated public order offence end, for example, and stirring up racial hatred begin. Further, the impacts of all three on a victim can be similar, though of course they can have different 'audiences'. Legally, however, they are quite separate, which is clearly demonstrated when considered in the context of the freedom of expression. Again, from a legal perspective, hate crime and stirring up hatred are typically structured differently - hate crime requiring that a criminal offence known to the law was committed with, for example, a racist motivation; and stirring up hatred being an offence proper, with no 'non-hate' version available.

\section{Terrorism}

With respect to terrorism, an interesting split has emerged, whereby it is generally understood as either a 'close cousin' or, conversely, a 'distant relative' to hate crime. On the one hand, a close affinity is argued on the basis of what are taken to be the core similarities between the two. In particular, great weight is placed on their shared intent to intimidate targeted communities, as well as the specific targeting of groups based on their identities (Krueger \& Malečková, 2002; Herek et al., 2002). In contrast, other scholars have insisted on conceptual, as well as legal, disparities between the two. Here, our attention is drawn to the relative lack of planning and organizational capacity typically associated with hate crime relative to terrorism (Deloughery et al., 2012), and the lack of deeply held ideological commitment underpinning many hate crimes (Levin \& McDevitt, 2002; Phillips, 2009). 
To date, much of the scholarship around terrorism has come from the disciplines of political science, international relations, or law. Sociologists and criminologists have come to the game very late, but have nonetheless begun to make substantial contributions to our theoretical understanding of terrorism and counter-terrorism(Turk, 2004; Black, 2004). Sociological frameworks that have fruitfully been applied have alternately conceptualized terrorism as a social construct; as political violence; as collective violence; as communication; as social organization; as learned behaviour; and as social control (Black, 2004; Turk, 2004). It is the latter model that we find most useful when thinking about the connections between terrorism and hate crime. Such an understanding enables us to see that terrorism, like hate crime, is an exercise of power intended to constrain and contain its victims. Interestingly, Jaggar offers a definition of terrorism as control which closely mirrors the sociological definition of hate crime that we adopted above (Perry, 2001). According to her, terrorism:

$\ldots$ is the use of extreme threats or violence designed to intimidate or subjugate governments, groups, or individuals. It is a tactic of coercion intended to promote further ends.. . Its threats or violence are aimed directly or immediately at the bodies or belongings of innocent civilians, but these are typically terrorists' secondary targets; the primary targets of terrorists are the governments, groups, or individuals that they wish to intimidate. (Jaggar, 2005, 209)

The parallels inherent in these definitions already draw us toward the likely conclusion that the two phenomena are similar in nature if not in scope. To further this analysis, we turn to Donald Black for insight into untangling this puzzling web that links potentially - hate crime to terrorism. In a series of articles, Black has articulated an account of terrorism as a form of social control in response to deviant behaviour. Immediately, this resonates with hate crime, which Perry (2001)characterizes as a means of constraining and punishing those who dare to step outside the boundaries of what is deemed their 'appropriate' place, defined according to their location on any number of relational hierarchies - race, gender, religion, or sexual orientation for instance (Perry, 2001). Black's utility does not end there, however. Following from his core definition of terrorism, Black identifies a series of characteristics that might be said to define terrorism. Heuristically, the seven derivative elements provide a useful tool by which to systematically contrast hate crime with terrorism. Arguably, hate crime mirrors terrorism on most dimensions, departing largely on questions of scale rather than kind. However, we highlight here just three salient dimensions. It is important to keep in mind throughout that the difficulty of this task is increased by the diversity of what we understand to be 'terrorists.' They are not homogeneous - there are, for example, those motivated by political aims, those motivated by anti-statism, and those motivated by racism. We take this up more fully in the section on extremism that follows. Here, we restrict our consideration to terrorism shaped by Othering.

First and foremost, there is no doubt that the intent of both terrorism and hate crime is to intimidate and instil fear both directly and indirectly. As the opening definitions suggests, perpetrators of both operate with the aim of terrorizing their targets individual and collective - into submission. Moreover, this intimidation is not only or even primarily - targeted at just the immediate victim. Rather, in both cases, the goal 
is to terrorize secondary victims. In the case of hate crime, the secondary targets are members of the victim's community - other Jewish people, or other Asian people, for example. The objects of terrorism are generally much broader, in that they include a not only the targeted community, but often a nation's people and/or their governing body.

Related to the motive is, of course, the impact. Hate crime generally has the effect of polarizing a national or local citizenry. It can pit neighbour against neighbour; it certainly instils inter-cultural hostility, thus threatening the stability and unity of a community - whether local or national. Terrorism can have a similar effect where the perpetrators are members of some identifiable group of 'others.' What motivates these attempts to intimidate is what Black refers to as a 'chronic grievance.' This is a useful characterization as it does not assume political or religious or economic or any other pre-ordained impetus. Rather, it leaves the ideological basis of the grievance open to account for myriad instigating factors. Looking at the 'work' of terrorists like White Aryan Resistance, for example, the grievance might be what they perceive as lax immigration law or loss of white male privilege. In a similar way, hate crime offenders are frequently reacting against what they perceive to be threatening behaviour on the part of their victim(s). Levin and McDevitt $(2002,1993)$ include a retaliatory motive in their typology of hate crime offenders, based on their observation that a notable proportion of offenders reported that their offence was a response to a prior (perceived or real) offence perpetrated against them.

However, there is an important distinction in the nature of these 'grievances.' Hate crime offenders are largely motivated by bias against, animosity towards or fear of the target community, whilst Sageman describes terrorism as 'political violence' (Sageman, 2017). While there is no commonly accepted reason as towhypeople become terrorists (Sageman, 2014), in contrast to those who commit hate crimes, we do know that they may be animated by more structurally grounded grievances, derived from an interpretation of a social order as itself illegitimate. There is a world of difference between the hate crime offender who attacks an English person because he thinks the British are 'arrogant snobs,' and the IRA operative who attacks the British state as part of the wider agenda of throwing off the yokes of oppression. Both Christian and Islamic extremists are waging a battle to 'maintain or restore a social order based on the fundamentals of faith, family and community against a rootless world order of abstract markets, mass politics and a debased sacrilegious 'tolerance" (Rosenfeld, 2004, 26). Further, there are different types of terrorism, some of which are closer in their nature to hate crime than others - environmental terrorism, for example, has little resonance for hate studies. Identity based terrorism - such as that perpetrated against the Muslim community in Christchurch New Zealand in 2019 - is much more closely aligned with hate crime. Some but not all nations capture this gamut of motivations in their terrorism legislation. The definition adopted in Canada, for example, refers to an act committed "in whole or in part for a political, religious, or ideological purpose, objective or cause with the intention of intimidating the public." In other words, some forms of terrorism are deemed motivated by identity-based differences, some by political causes.

Comparatively, then, terrorism and hate crime share some level of kinship. One might say particular forms of terrorism run along the same continuum of intimidation and fear as does hate crime. They differ largely in degree rather than kind. The motives may be similar - ethnic or racial animosity for example, and in both cases the intent is 
to intimidate, to silence, perhaps to socially or even physically marginalize the targeted community. But while both have proximal and distal victims, terrorism is likely to have greater quantitative impacts to the extent that a broader swath of the community is caught in the line of fire.

Yet how is this assessment useful? On the one hand, it encourages us to take hate crime seriously. It could evolve into terrorism, as it can among organized hate groups and their followers, for example. We have seen this in the dramatic rash of lone actor mass violence that has struck Christchurch NZ, and Pittsurgh US, inter alia. Conversely, this assessment of the parallels between hate crime and terrorism allows us to see the latter in somewhat more familiar and comprehensible terms. Hate crime is a phenomenon about which we are beginning to learn a great deal. Such knowledge may, in fact, enable us to better understand the dynamics and motivations of identity-based terrorism as well. Again, it shares the same continuum as hate crime, while clearly occupying the extreme end of the scale.

\section{Genocide}

Scholarship seeking to understand and define genocide draws, either consciously or unconsciously, from the same theoretical underpinnings as hate crime, but also distinguishes the crime from that of terrorism. Originally coined by Lemkin (1944) the term was described as the systematic destruction of a nation or people:

Generally speaking, genocide does not necessarily mean the immediate destruction of a nation, except when accomplished by mass killings of all members of a nation. It is intended rather to signify a coordinated plan of different actions aiming at the destruction of essential foundations of the life of national groups, with the aim of annihilating the groups themselves. The objectives of such a plan would be disintegration of the political and social institutions, of culture, language, national feelings, religion, and the economic existence of national groups, and the destruction of the personal security, liberty, health, dignity, and even the lives of the individuals belonging to such groups.... (1944, 79)

Adapting this definition, the UN Convention on the Prevention and Punishment of the Crime of Genocide defines the term as a series of acts 'committed with intent to destroy, in whole or in part, a national, ethnical, racial or religious group...' (1948). ${ }^{2}$ Importantly, genocidal acts go beyond just the killing of individuals, and include other forms of violence up to and including rape. From a definitional perspective, in as much as one of the key debates in hate studies scholarship is the identity groups which deserve protection under hate crime legislation (see, for example, Al-Hakim, 2015; Mason, 2014; Schweppe, 2012), a parallel debate occurs in the context of genocide,

\footnotetext{
${ }^{2}$ These acts are: '(a) Killing members of the group; (b) Causing serious bodily or mental harm to members of the group; (c) Deliberately inflicting on the group conditions of life calculated to bring about its physical destruction in whole or in part; (d) Imposing measures intended to prevent births within the group; (e) Forcibly transferring children of the group to another group."
} 
with, for example, Kakar (1995)arguing that social and political groups should be incorporated within the definition, and Axelson (2016) arguing that sexual orientation should be included.

As the most extreme form of identity-based persecution, genocide is rightly seen legally, culturally, and sociologically as being in a different class of violence, described by Turpin-Petrosino as 'the most extreme case of intergroup hatred' (TurpinPetrosino, 2015, 191). Where other manifestations of hate involve 'Othering', genocide involves 'extreme dehumanisation' which ends in the mass murder of members of an identity group or groups. Turpin-Petrosino lists examples of genocide:

Besides the Holocaust, there have been many genocides including the Lakota Sioux, Yuki, Arapaho, and Cheyenne, tribes that were decimated by military and other authorities throughout the early (North) American history; through the execution of periodic pogroms during the nineteenth and twentieth centuries, the Ottoman Turks murdered thousands of Armenians (Europe); Stalin killed millions of Ukrainians during the 1930s (Asia); and the Rwandan genocide saw nearly a million Tutsi killed in about 100 days (Africa) (Turpin-Petrosino, 2015, 191-192).

Like terrorism, then, genocide is distinct from hate crime only in its intensity and scale. Indeed, it is at the extreme end of the continuum that begins with microaggressions, running through hate crime, and perhaps terrorism. It takes us beyond assaults on a community with the intent to intimidate into silence or compliance, into the realm of eradication of the reviled other. Unlike hate crime, it is not simply targeted against a random proxy for the community of which they are a part. Rather, it is a wholesale attempt to stamp out all of its members.

It must also be noted that genocide is systematic rather than individual. The same can be said of hate crime, which hate is not simply grounded in a mental state; nor is it the outcome of extreme hostility or pathology. Rather, it is more often foreseeable, and rational, at least from within the worldview of the perpetrator. It is systemic, resonating with a network of norms, assumptions, behaviors, and policies that are structurally connected in such a way as to reproduce the identity-based hierarchies that characterize so many Western cultures. Similarly, from the perspective of the perpetrators, Gaylin (2003)observes that genocide is not the product of the deranged: the atrocities carried out in acts of genocide are discharged, he says, 'not by psychotics and psychopaths but by normal members of the population.' Thus, the same dangers of individualizing and pathologising hate crime apply in the context of genocide. Genocides are not carried out by the deranged but rather "enacted by "normal" individuals who are placed in extraordinary circumstances' (Jacks \& Adler, 2015, 373).

Sternberg and Sternberg (2008), 6) note that in the context of the Holocaust, Serbia and Rwanda, hate was cynically fomented by those in power, so that they could maintain or attain power. Thus, hate can be a powerful political tool when fomented in citizens. Indeed, Chapman notes that hate speech will often be utilised at an early stage in the genocidal process to identify the targeted community as 'other' (Chapman, 2014, 35). This 'othering' is a necessary step in identifying the targeted community as not being protected by the usual rules of social behaviour 
(Chapman, 2014). Again, we see the continuum of hatred in operation here, with hate speech being used cynically and deliberately to sustain or achieve power in the context of the most extreme and vicious form of hate act. This hate speech takes both the dehumanising form of 'othering', but also, as in Rwanda, can take the form of incitements to violence, where a radio station broadcasted incitements for Hutus to slaughter their Tutsi neighbours (Sternberg \& Sternberg, 2008). Danner makes the connection between hate crime and genocide explicit: referring to the examples of genocide in the twentieth century, she observes that the crimes against humanity were preceded by less violent forms of discrimination 'that indicated to the larger society that these groups were appropriate targets of discrimination, and ultimately, destruction.' (2002, 413).

As we have noted earlier, this continuum of hatred, from hate speech to genocide is recognised in the United Nations Convention on the Prevention and Punishment of the Crime of Genocide. In this lead up process, hate crime can also be used as a tool of oppression, but Chapman argues that there is a distinction between the lead-up to conflict, and war crimes committed against civilians on the basis of their identity within a conflict setting. In the lead up, the intent is to intimidate a population, to provoke acts of retaliation, or to normalise violence. During the conflict environment, she states, acts 'may have a more immediate tactical goal' $(2014,35)$. She observes that in the absence of measures - both criminal and educative - aimed at addressing hate speech and hate crime post-conflict, there is a risk that those lower order offences have the ability to tip the balance of peace back into conflict. Thus, hate speech and hate crime are not only tools used at the early stages of the process, but can also be used to ensure the cycle continues.

Regardless of the boundaries of in/exclusion, it is evident that genocide, which has the intention of annihilating an entire group, is the ultimate exercise in the violence of Othering. It is hard to see how it could possibly be related to what might be considered the banality of microaggression, but the example from Rwanda we discussed earlier shows clearly how hate speech can form a justification for the later intensification of violence and, ultimately, genocide.

\section{Extremism: A conceptual conundrum}

So far, our articulation and understandings of varying manifestations of hatred and prejudice have not posed or exposed any significant disciplinary distinctions, but rather our two perspectives have allowed for the mutual framing of concepts in our efforts to shape and define the field. Once we probed and articulated our disciplinary perspectives on extremism, however, this mutual framing met an impasse. From a definitional point of view, extremism is a woolly concept within the literature, and there is no such construct from a legal perspective. Extremism, then, is in one sense, a state of mind: a perspective on the world which is informed by deeply held but extreme political or religious views. Coleman and Bartoli define extremism as 'activities (beliefs, attitudes, feelings, actions, strategies) of a character far removed from the ordinary.' $(2015,2)$ Wintrobe suggests that there are three types of extremists: those who are (1) extreme by method but not by goal; (2) those that are extreme by goal and method; and (3) those that are extreme by goal but not method $(2006,84)$. Schmid observes that while we 
might think of the first category of extremists as 'acceptable extremists', this is a premature conclusion, since 'the absence of violence might be only a temporal tactical consideration' $(2014,12)$. Further, if we consider hate speech as a social and (sometimes) legal harm, then the 'keyboard extremists' who engage in online hate speech, which has a global reach and impact should still be considered unacceptable in our field. When we consider the three types of extremists in our continuum, they may engage in anything from microaggressions to genocide. Thus, while the philosophical basis for their actions may come from a place of extremism, their actions - which the law is typically concerned with - are addressed at other stages on our continuum.

Further, while hate scholars would typically think of far right or white supremacist extremists in this context, we must also consider other forms of extremism as part of the overall concept prior to determining the space or place extremism(s) hold within a framework of hate studies. Gregory (2010) describes the types of extremism that have concerned the British police force since 1945, which include communists, Irish republicans, nationalist groups such as the Popular Front for the Liberation of Palestine and the Palestine Liberation Organisation, animal-rights groups, anti-capitalist groups, anarchist groups, right-wing extremist groups, and Islamist extremists. Clearly, not all of these 'extremist' organisations can be or should be considered within the field of hate studies. Is it possible, then, to delimit the type of extremists that are within the field, and those that are not, or should extremism be considered allied to but outside the field? This issue particularly poses a thorny question for those conceptualising the field: while hate crime, hate speech, terrorism (mostly) and genocide have othering as core to the conception, and microaggressions are often termed 'hate incidents' by scholars, policy makers and practitioners, extremism takes forms which are conceptually both within and outside the continuum and the field. Further, if we take the definition of 'extremism' as widely understood, then, for example, it is only those who engage in racist or religious, and perhaps misogynistic extremism that can be considered: homophobia, disablism, or transphobia, sadly, are not 'extreme' positions in society. It is not, according to the literature at least, possible to be a 'homophobic extremist'. Can a field of study which is inclusionary to its core really embrace a concept which is by definition exclusionary?

Ultimately, we must ask whether, from the perspective of the field of hate studies, we can draw a boundary around those extremists, the activities and attitudes of whom are considered within the field and those that are not. Certainly it is arguable that those extremists who engage in the othering of communities on the basis of their identity are part of the field, and indeed in some cases connect the continuum from hate crime to terrorism To include such extremists, we would have to limit the wider concept by including only identity-based extremists within the field, which would arguably fill the grey area between hate crime and terrorism.

Consider the example of the Quebec City mosque shooting we considered at the outset. That incident arguably sits in some liminal space between hate crime and terrorism leading us to the conclusion that there is a conceptual space between hate crime and terrorism with no 'label', that of identity-based extremism. Similarly, another example is the Orlando Pulse Massacre, where a lone gunman killed 49 people and wounded a further 58 others in what has variously been described as a mass shooting or an act of terrorism - the latter because of his pledged allegiance to ISIS, not because of his homophobic motivation. If this link to ISIS had not been articulated, however, the 
gunman Omar Mateen would not and could not have been described as an 'extremist': homophobia is not an 'extremist' position.

Thus, the label of 'extremist' or extremism is applied in a discretionary way, and generally shaped by politics rather than careful scholarly consideration. In some respects, it is simply a meaningless label, applied to those individuals who cross the boundaries from what is considered by society to be absolutely unacceptable, and not applying to others who believe and act with equal vehemence in relation to other categories of individuals. Further, if the field of hate studies is closely aligned to legal processes, and reflected in legal definitions, then extremism is simply a state of mind, with acts of those who hold those beliefs addressed with other labels associated with the field (most usually, incitement to/stirring up hatred, hate crime, terrorism). Thus, on one understanding, extremism is not related to hate studies, first, not being shaped by, or capable of shaping, a legal frame; second, by including perspectives which are not 'Othering' in their nature; and third, being exclusionary by definition. However, there is a particular category of offenders and activities which deserve - and arguably demand particular attention by scholars in the field of hate studies: can we truly have a field of hate studies and demand the exclusion of considerations of white supremacy, its impacts, ideologies and effects? In this short articulation of the continuum of hatred and the field of hate studies, extremism thus poses a conceptual conundrum.

\section{Conclusion}

Our intent here is to initiate further dialogue on the domain of hate studies (Blitzer, 2005/2006; Stern, 2003/2004) by parsing out the likely relationships among and between an array of violent strategies concerned with Othering. We have located hate crime along a continuum of force, intimidation, and escalation relative to other phenomena like microaggressions, terrorism and genocide. In short, we have begun to explore the continuities and discontinuities that characterize the expanding field of hate studies. Recall that at the outset we identified a number of elements that seemed to characterize hate crime, which we used as proxy criteria for our consideration of whether other forms of Othering corresponded in any way. We argued that the fields we have explored here are clearly all identity-based, that is, shaped by the juxtaposition of the victims' and offenders' relative positioning along lines such as race, gender, sexual orientation, and religion. This positioning is (re)established through the organizing structures noted here in such a way as to signal if not enforce the marginality of the target group. Because each of the phenomena in question both target and signify individuals and collectives, they have both proximal and distal impacts. That is, they target not just individuals associated with a group, but also the group as a whole. They are all, like hate crimes, disseminated as messages to the despised group, reminding them of their "rightful" - i.e., subordinate - place in relevant social hieararchies.

Admittedly, we occasionally found ourselves at odds given our very different disciplinary training. For obvious reasons, the legal scholar was concerned that we limit our understandings of specific terms to legally defined constructs. In contrast, the criminologist typically held a wider view of behaviours and conduct not restricted to those defined under the law, criminal or otherwise. However, that is perhaps the beauty of this multi- and inter-disciplinary field of study. It is the tensions that derive from 
diverse and often divergent perspectives that allow us to identify and address gaps in our understanding and responses to hate crime. It does, however, also have its drawbacks - there are sometimes theoretical and practical differences in what we, across the disciplines, understand as 'hate crime' meaning that we on occasion speak at odds when discussing phenomena. Does this mean, then that we need to reconceptualise our terminology, or narrowly frame our discussions from a disciplinary context? When comparing and contrasting findings in empirical research, the very question of the difference between legal and conceptual/sociological definitions becomes an important point of discussion.

To date, the field of what is described as 'hate studies' has been relatively narrowly constructed as to do with hate crime, and more recently, extremism. As hate studies reaches maturity, we hope that we have begun to highlight the complexities of defining the field. By no means do we claim to have exhausted the range of potential expressions of hatred. Our intent, rather, has been to offer provocation for further reflection on how narrowly or broadly we might define our field, and on what grounds. As academics working in this area, we nimbly borrow from and engage with disciplines outside our own. It is time, we believe, for us to move beyond academic silos, and learn from other areas of 'difference-making' to expand our understanding of hate.

Acknowledgements The Authors would like to thank Professor Amanda Haynes, University of Limerick, for her helpful comments on a previous draft of this article.

Funding Open Access funding provided by the IReL Consortium. Funding was received from the University of Limerick International Activity Challenge Fund to support our collaboration.

Open Access This article is licensed under a Creative Commons Attribution 4.0 International License, which permits use, sharing, adaptation, distribution and reproduction in any medium or format, as long as you give appropriate credit to the original author(s) and the source, provide a link to the Creative Commons licence, and indicate if changes were made. The images or other third party material in this article are included in the article's Creative Commons licence, unless indicated otherwise in a credit line to the material. If material is not included in the article's Creative Commons licence and your intended use is not permitted by statutory regulation or exceeds the permitted use, you will need to obtain permission directly from the copyright holder. To view a copy of this licence, visit http://creativecommons.org/licenses/by/4.0/.

\section{References}

Al-Hakim, M. (2015). Making a home for the homeless in hate crime legislation. Journal of Interpersonal Violence,30(10), 1755-1781. https://doi.org/10.1177/0886260514549197.

Association of Chief Police Officers (ACPO) (2018). Truevision: 'What is hate crime?' http://report-it.org.uk/ what_is_hate_crime. Accessed 23 Nov 2018.

Axelson, R. (2016). State-sponsored hatred and persecution on the grounds of sexual orientation: The role of international criminal law. In J. Schweppe \& M. Walters (Eds.), The globalisation of hate (pp. 247-262). Oxford University Press.

Black, D. (2004). Terrorism as social control. In M. Deflem (Ed.), Terrorism and counter-terrorism: Criminological perspectives (pp. 9-18). Elsevier.

Blitzer, J. (2005/2006). Toward an interdisciplinary field of hate studies: Developing a framework. Journal of Hate Studies, 4(1), 139.

Boeckmann, R. J., \& Turpin-Petrosino, C. (2002). Understanding the harm of hate crime. Journal of Social Issues, 58(2), 207-225.

Bowling, B. (1998). Violent racism: Victimisation, policing and social context. Oxford University Press. 
Brudholm, T. (2016). Conceptualizing hatred globally: Is hate crime a human rights violation? In J. Schweppe \& M. A. Walters (Eds.), The globalization of hate: Internationalizing hate crime? (pp. 31-49). Oxford University Press.

Brudholm, T. (2020). What is hate? In R. Sternberg (Ed.), Perspectives on hate: How it originates, develops, manifests and spreads (pp. 65-87). American Psychological Association.

Campo Engelstein, L. (2016). Rape as a hate crime: An analysis of New York law. Hypatia, 31(1), 91-106.

Chakraborti, N., \& Garland, J. (2015). Hate crime: Impact, causes and responses (2nd ed.). Sage.

Chapman, C. (2014). The role of hate speech and hate crime in the escalation of identity conflict. State of the world's minorities and indigenous peoples. Available at https:/d1wqtxts1xzle7.cloudfront.net/42655506/ SWM_hate_speech_conflict_FINAL.pdf?1455397950=\&response-content-disposition=inline\%3B+ filename\%3DThe_role_of_hate_speech_and_hate_crime_i.pdf $\&$ Expires $=1627307436 \&$ Signature $=$ dNt5p9pTLUxrjgvG4LRIddO47MfBEpceneSzzZd1OMdS1sjjfNkGPIWjyFFj8sEKnNMJN96KYa8cS4zO6Rbh7bKYlx 7ixo9vqwHuShoXeT-OPntVd9EI PadILxmFoDwJ-GofQnChfn8W6AI-MjSUXX $\sim$ ZOX7AORwHq6zoJjzQQ7vN3JUEdPyUYdvmwaHL8p41RpP7JGGTT8h -S wSPJGa2NHaUqOoa8sL94iQi3nwnUVJuhpZQ34Ftkt3tfir3FFisjNObQqSCu6Xhvjhm3jybJmEYCC L698UfOy602N1VfC 8cpVI3ZLMvDlqGYRjEnV3Ln6imtvChvqMzy87A_\&Key-Pair-Id= APKAJLOHF5GGSLRBV4ZA

Coleman, P. T., \& Bartoli, A. (2015). Addressing extremism [White paper]. The International Center for Cooperation and Conflict Resolution, Colombia University. http://www.tc.columbia.edu/i/a/document/ 9386_WhitePaper_2_Extremism_030809.pdf.

Constantine, M. G. (2007). Racial microaggressions against African American clients in cross-racial counseling relationships. Journal of Counseling Psychology, 54, 1-15.

Corcoran, H., Lader, D., \& Smith, K. (2015). Hate crime, England and Wales, 2014/2015. Home Office.

Cunneen, C. (1997). Hysteria and hate: the vilification of Aboriginal and Torres Strait Islander people. In C. Cunneen, D. Fraser, \& S. Tomsen (Eds.), Faces of hate: Hate crime in Australia (pp. 137-161). Hawkins Press.

Danner, A. M. (2002). Bias crimes and crimes against humanity: Culpability in context. Buffalo Criminal Law Review, 6(1), 389-450.

Deloughery, K., King, R. D., \& Asal, V. (2012). Close cousins or distant relatives? The relationship between terrorism and hate crime. Crime \& Delinquency, 58(5), 663-688.

Dougherty K. (2017). Quebec mosque shooting suspect was a fan of Donald Trump and Marine le Pen. Independent, 31 January. Retrieved from http://www.independent.co.uk/news/world/americas/quebeccity-mosque-shooting-latest-alexandre-bissonnette-donald-trump-marine-le-pen-facebook-sociala7554451.html

European Union Agency for Fundamental Rights. (2012). Making hate crime visible in the European union: Acknowledging victims' rights. Publications Office of the European Union. Available at https://fra.europa. eu/sites/default/files/fra-2012_hate-crime.pdf

Frye, M. (2007). Oppression. In P. Rothenberg (Ed.), Race, class, and gender in the United States (7th ed., pp. 154-157). Worth Publishers.

Garland, J., \& Funnell, C. (2016). Defining hate crime internationally: Issues and conundrums. In J. Schweppe \& M. A. Walters (Eds.), The globalization of hate: Internationalizing hate crime (pp. 15-31). Oxford University Press.

Gaylin, W. (2003). Hatred: The psychological descent into violence. Public Affairs.

Gerstenfeld, P. B. (2013). Hate crimes: Causes, controls and controversies. Sage.

Glimmerveen and Hagenbeek v The Netherlands Application Numbers 8348/78 and 8406/78. (n.d.)

Goldberg, D. T. (1995). Afterword: Hate or power? In R. K. Whillock \& D. Slayden (Eds.), Hate speech (pp. 267-276). Sage

Goodall, K. (2010). Challenging hate speech: Incitement to hatred on grounds of sexual Orientation in England, Wales and Northern Ireland. In P. Chan (Ed.), Protection of sexual minorities since stonewall: Progress and stalemate developed and developing countries. Routledge.

Gregory, F. (2010). Policing the 'new extremism' in twenty-first-century Britain. In R. Eatwell \& M. Goodwin (Eds.), The new extremism in $21^{\text {st }}$ century Britain (pp. 85-103). Routledge.

Hall, C. (2009). Sticks and stones may break my bones but will the law ever protect me: Ensuring educational access through Federal Prohibition of Peer-on-Peer Harassment. Children's Legal Rights Journal, $29,42$.

Hall, N. (2005). Hate crime. Willan

Haynes, A., \& Schweppe, J. (2017). Lifecycle of a hate crime: Country report for Ireland. https://www.iccl.ie/ wp-content/uploads/2018/05/Hate-Crime-Report-LR-WEB.pdf. Accessed 23 November 2018.

Herek, G., \& Berrill, K. (1992). Hate crimes: Confronting violence against lesbians and gay men. Sage. 
Herek, G. M., Cogan, J. C., \& Gillis, J. R. (2002). Victim experiences in hate crimes based on sexual orientation. Journal of Social Issues, 58, 319-339.

Hodge, J. P. (2011). Gendered hate: Exploring gender in hate crime law. UPNE.

Iganski, P. (2008). Hate crime and the city. The Policy Press.

Jack, W., \& Adler, J. R. (2015). Genocide and hate crime. In D. Crighton \& G. Towl (Eds.), Forensic psychology (BPS Textbooks in Psychology, pp. 369-381). Wiley.

Jaggar, A. (2005). What is terrorism, why is it wrong, an could it ever be morally permissible? Journal of Social Psychology,36(2), 202-217.

Jenness, V. (2002). Contours of hate crime politics and law in the United States. In P. Iganski (Ed.), The Hate Debate (pp. 15-35). Profile Books.

Kakar, M. H. (1995). Afghanistan: The Soviet Invasion and the Afghan Response, 1979-1982. University of California Press, The Regents of the University of California. http://content.cdlib.org/xtf/view?docld= $\mathrm{ft} 7 \mathrm{~b} 69 \mathrm{pl} 2 \mathrm{~h} \& \mathrm{brand}=\mathrm{eschol}$

Kellow, C. L., \& Steeves, H. L. (1998). The role of radio in the Rwandan genocide. Journal of Communication, 48(3), 107-128.

Kelly, R. (1993). Bias crime: American legal responses. Office of International Criminal Justice.

Kiska, R. (2012). Hate speech: A comparison between the European court of human rights and the United States supreme court jurisprudence. Regent University Law Review, 25, 107-151.

Krueger, A.B., \& Malečková, J. (2002). The economics and the education of suicide bombers: Does poverty cause terrorism?. The New Republic, 27-33.

Lemkin, R. (1944). Axis rule in occupied Europe. Carnegie Endowment for International Peace.

Levin, J., \& McDevitt, J. (1993). Hate Crimes: The Rising Tide of Bigotry and Bloodshed. Plenum.

Levin, J., \& McDevitt, J. (2002). Hate crimes revisited: America's war on those who are different. Westview Press.

Macpherson, W. (1999). The Stephen Lawrence Inquiry [online]. https://assets.publishing.service.gov.uk/ government/uploads/system/uploads/attachment_data/file/277111/4262.pdf.

Mason, G. (2014). Victim attributes in hate crime law. British Journal of Criminology,54, 161-179. https:// doi.org/10.1093/bjc/azt073.

McDevitt, J., Balboni, J., Garcia, L., \& Gu, J. (2001). Consequences for victims: A comparison of bias- and non-bias motivated assaults. American Behavioral Scientist,45(4), 697-711.

McPhail, B. (2002). Gender Bias Hate Crimes. Trauma, Abuse and Violence, 3(2), 125-143.

Nadal, K. L. (2008). Preventing racial, ethnic, gender, sexual minority, disability, and religious microaggressions: Recommendations for promoting positive mental health. Prevention in Counseling Psychology: Theory, Research, Practice and Training, 2(1), 22-27.

Nadal, K. L., Issa, M. A., Leon, J., Meterko, V., Wideman, M., \& Wong, Y. (2011). Sexual orientation microaggressions: 'Death by a thousand cuts' for lesbian, gay, and bisexual youth. Journal of LGBT Youth, 8(3), 234-259.

Norwood v United Kingdom 16 November 2004. Application number 23131/03. (n.d.)

Ontario Human Rights Commission. (2003). Paying the price: The human cost of racial profiling. Ontario Human Rights Commission.

OSCE/ODIHR (2009). Hate crime laws - A practical guide. https://www.osce.org/odihr/36426.

Paterson, J., Brown, R., \& Walters, M. (2018a). Understanding victim group responses to hate crime: Shared identities, perceived similarity and intergroup emotions. TPM: Testing, Psychometrics, Methodology in Applied Psychology, 25(2), 163-177.

Paterson, J. L., Brown, R., \& Walters, M. A. (2019). The short and longer term impacts of hate crimes experienced directly, indirectly and through the media. Personality and Social Psychology Bulletin,45(7), 994-1010.

Paterson, J., Walters, M., Brown, R., \& Fearn, H. (2018b). The Sussex hate crime project: Final report. University of Sussex.

Pejchal, V., \& Brayson, K. (2016). How should we legislate against hate speech? Finding an international model in a globalized world. In J. Schweppe, \& M. Walters (Eds.), The globalisation of hate (pp. 247262). Oxford University Press

Perreaux, L., \& Freeze, C. (2017). Arrest made after hate crimes spike following Quebec mosque attack. Globe and Mail, 1 February. Retrieved from http://www.theglobeandmail.com/news/national/policereport-rise-in-hate-crimes-after-quebec-city-mosque-attack/article33856702

Perry, B. (2001). In the name of hate: Understanding hate crimes. Routledge.

Perry, B. (2003). Where do we go from here? Future directions in hate crime scholarship. Internet Journal of Criminology. www.flashmousepublishing.com. 
Perry, B. (2009). 'There's just places ya' don't wanna go': The segregating impact of hate crime against native Americans. Contemporary Justice Review, 12(4), 401-402.

Perry, B., \& Alvi, S. (2012). 'We are all vulnerable': The in Terrorem effects of hate crimes. International Review of Victimology, 18(1), 57-71.

Perry, B., \& Dyck, R. (2014). "I don't know where it is safe": Trans women's experience of violence. Critical Criminology,22(1), 49-63.

Perry, B., \& Olsson, P. (2009). Hate crime as a human rights violation. In P. Iganski (Ed.), The impacts of hate crime. Praeger.

Phillips, N. D. (2009). The prosecution of hate crimes: The limitations of the hate crime typology. Journal of Interpersonal Violence, 24, 883-905.

Phillips, S., \& Grattet, R. (2000). Judicial rhetoric, meaning-making and the institutionalization of hate crime law. Law and Society Review, 34(3), 567-572.

RAV v City of St Paul 505 US 377 (1992).

Ray, L., \& Smith, D. (2001). Racist offenders and the politics of 'hate crime'. Law and Critique, 12, $203-221$.

Rosenfeld, R. (2004). Terrorism and criminology. In M. Deflem (Ed.), Terrorism and counter-terrorism: Criminological perspectives (pp. 19-32). Elsevier.

Sageman, M. (2014). The stagnation in terrorism research. Terrorism and Political Violence,26(4), 565-580. https://doi.org/10.1080/09546553.2014.895649.

Sageman, M. (2017). Turning to political violence: The emergency of terrorism. University of Pennsylvania Press. https://doi.org/10.9783/9780812293821

Schmid, A. P. (2014). Violent and non-violent extremism: Two sides of the same coin. ICCT Research Paper, pp. $1-29$

Schweppe, J. (2012). Defining characteristics and politicising victims: A legal perspective. Journal of Hate Studies,10(1), 173-198. Retrieved from: http://journals.gonzaga.edu/index.php/johs/article/view/183

Schweppe, J. (2021). What is a hate crime? Cogent Social Sciences, 7(1). https://doi.org/10.1080/23311886. 2021.1902643

Schweppe, J., Haynes, A. \& Walters, M.A. (2018). Lifecycle of a hate crime: Comparative report.

Shively, M. (2005). Study of literature and legislation on hate crime in America. National Institute of Justice.

Stern, K. S. (2003/2004). The need for an interdisciplinary field of hate studies. Journal of Hate Studies, 3(1), 7.

Sternberg, R. J., \& Sternberg, K. (2008). The nature of hate. Cambridge University Press.

Sue, D., Capodilupo, C., \& Holder, A. (2008). Racial microaggressions in the life experience of black Americans. Professional Psychology: Research and Practice, 39(3), 329-336.

Turk, A. (2004). Sociology of terrorism. Annual Review of Sociology,30, 271-286.

Turpin-Petrosino, C. (2015). Understanding hate crimes: Acts, motives, offenders, victims, and justice. Routledge.

Waldron, J. (2012). The harm in hate speech. Harvard University Press.

Walters, M. A. (2014). Hate crime and restorative justice: Exploring causes. Oxford University Press.

Walters, M. A., Paterson, J. L., McDonnell, L., \& Brown, R. (2020). Group identity, empathy and shared suffering: Understanding the 'community' impacts of anti-LGBT and Islamophobic hate crimes. International Review of Victimology,26(2), 143-162. https://doi.org/10.1177/0269758019833284

Walters, M. A., \& Tumath, J. (2014). Gender 'hostility', rape, and the hate crime paradigm. The Modern Law Review, 77(4), 563-596.

Wang, L. (1999). The complexities of "hate". Ohio State Law Journal,60, 799-898.

Wessler, S. (2000). Sticks and stones. Educational Leadership, 58(4), 28-33.

Wieland, J. (2007). Peer-on-peer hate crime and hate-motivated incidents involving children in California's public schools: Contemporary issues in prevalence, response and prevention. University of CaliforniaDavis Journal of Juvenile Law and Policy, 11, 235.

Wintrobe, R. (2006). Rational extremism: The political economy of radicalism. Cambridge University Press. Wisconsin v Mitchell 506 US 476 (1993).

Yanagizawa-Drott, D. (2014). Propaganda and conflict: Evidence from the Rwandan genocide. The Quarterly Journal of Economics, 129(4), 1947-1994.

Young, I. M. (1990). Justice and the politics of difference. Princeton University Press.

Publisher's note Springer Nature remains neutral with regard to jurisdictional claims in published maps and institutional affiliations. 